\title{
Bio-Oil Production from Cirsium yildizianum through Pyrolysis in a Fixed-Bed Reactor
}

\author{
Tevfik Aysu ${ }^{1, *}$ and Aydin Şükrü Bengü² \\ ${ }^{1}$ Department of Chemistry, Yuzuncu Yil University, Faculty of Education, 65080, Van, Turkey \\ ${ }^{2}$ Central Research Laboratory, Bingol University, Bingol, Turkey
}

\begin{abstract}
Pyrolysis of Cirsium yildizianum samples were carried out in a fixed-bed tubular reactor with (tincal, colemanite and ulexite) and without catalyst catalyst at three different temperatures $\left(350,450,550{ }^{\circ} \mathrm{C}\right)$ with a constant heating rate of $50{ }^{\circ} \mathrm{C} / \mathrm{min}$. The yields of bio-char, bio-oil and gas produced along with the compositions of the resulting bio-oils were determined by elemental, Fourier transform infrared spectroscopy (FT-IR) and Gas chromatography/ mass spectrometry (GC-MS). The effects of pyrolysis parameters including temperature and catalyst on product yields were investigated. The results indicate that both temperature and catalyst had signficant effect on conversion of Cirsium yildizianum into solid, liquid and gas products. The highest liquid (bio-oil) yield of $40.62 \%$ including aqueous phase was obtained in the presence of colemanite $(10 \%)$ as catalyst at $550^{\circ} \mathrm{C} .79$ different compounds were identified by GC-MS in bio-oils obtained at $550{ }^{\circ} \mathrm{C}$
\end{abstract}

Keywords: Biomass, Pyrolysis, Bio-oil, Catalyst, Cirsium yildizianum.

\section{INTRODUCTION}

In recent years, the continuing utilization of fossil fuels has resulted in environmental pollution, global warming and acid rains. The steadily increasing market price and shortage of fossil fuels has caused energy crisis in the world. These issues have driven the worldwide efforts to explore new alternative and renewable fuels that are sustainable and environmentally friendly. Among them, biomass is considered to be one of the most promising candidates due to its renewability, carbon neutrality and high productivity. Biomass is one of the most abundant sources of renewable energy and is an important candidate for sustainable energy systems in the future. In this regard, the production of alternative energy, fuels and value-added chemicals from biomass has attracted great attention in recent years [1-3]. In addition to direct combustion, biomass can be easily converted into fuels and chemicals by using different conversion methods [4]. The biomass conversion technologies are mainly divided into biochemical and thermochemical such as liquefaction, pyrolysis and gasification [5-7].

Lignocellulosic biomass has a complex structure which is consists of $40-50 \%$ cellulose, $20-35 \%$ hemicellulose and $20-40 \%$ lignin depending on the source. This composition and lignocellulosic stability make a selective conversion toward specific products or product classes quite difficult because different bond

*Address correspondence to this author at the Department of Chemistry, Yuzuncu Yil University, Faculty of Education, 65080, Van, Turkey; Tel: 90432 22517 02; Fax: 9043222513 69; E-mail: tevfikaysu@yyu.edu.tr types have to be cleaved and it necessitates more drastic conditions such as high temperature and pressure in addition to specific separation technologies [8]. Direct combustion for production of heat, gasification for production of syngas, pyrolysis and liquefaction for production of bio-oil are the most commonly used methods applied for converting biomass into energy or fuels. The bio-oil production methods seem to be privileged due to its higher energy density output and it is easier to transport and store than bulky solid biomass itself or gaseous products [3].

Pyrolysis, a thermochemical conversion process, is one of the many ways to convert biomass into other forms, such as fuel that is more conveniently used, transported or stored. Pyrolysis of biomass is performed at elevated temperatures $\left(400-1000{ }^{\circ} \mathrm{C}\right)$ in the absence of oxygen gas [9]. The distribution of pyrolysis products depends on the composition of biomass feedstock. Each biomass sample with different component ratios shows unique characteristics under pyrolysis conditions [10]. Biomass pyrolysis result in formation of liquid (water and tar) and gaseous $\left(\mathrm{H}_{2}, \mathrm{CH}_{4}, \mathrm{CO} \& \mathrm{CO}_{2}\right)$ products and leaves a solid residue known as charcoal [11]. The liquid product, tar which could be used as a fuel is also know bio-oil, pyrolysis oil or bio-crude [12]. Bio-oil obtained from pyrolysis of biomass is dark brown mixtures of organic compounds including acids, alcohols, aldehydes, esters, ketones, sugars, phenols, guaiacols, syringols, furans and phenols. They have higher heating values than that of raw materials and can be easily transported and stored. They have the potential for substitution of fuel-oils and can be used to generate 
heat and electricity or to produce value added chemicals. However, they have lower quality compared to fossil fuels and can not be mixed with them as they contain high amounts of oxygen ranging between 35$45 \mathrm{wt} \%$. Consequently, they can not be used directly in conventional gasoline or diesel engines [13]. There are other disadvantages of bio-oils such high water content (15-30 wt \%), acidity coming from formic and acetic acids, high viscosity varying in a large range and presence of ash higher than $0.1 \mathrm{wt} \%$. In order to improve the quality of bio-oils, several upgrading processes including hydrodeoxygenation, catalytic cracking, emulsification, steam reforming are required to reduce oxygen content and viscosity and to increase volatility and thermal stability [14].

Among the upgrading techniques of bio-oils, catalytic cracking has been used widely as a convenient method by many researchers. Oxygen containing bio-oils are catalytically decomposed to hydrocarbons with the removal of oxygen as $\mathrm{H}_{2} \mathrm{O}, \mathrm{CO}_{2}$ or CO [12]. In a previous study [15], hydrothermal liquefaction of beech wood were carried out at 250, 300 and $350{ }^{\circ} \mathrm{C}$ using borax decahydrate and sodium borohydride as catalyst. The effects of both temperature and catalysts on the product distributions and bio-crude compositions were investigated and found that the use of both catalysts have increased biocrude yields at all liquefaction temperatures. The heating values of ether extracts from all experimental runs including the run without catalyst were close to each other. However, the heating values of the acetone extract from chemical runs were higher than the heating values of the non-chemical run. The identified compounds in ether extracts and acetone extracts were mainly oxygenated compounds. The compositions of ether extract and acetone extract were affected with catalyst. In a recent study [16] thermal and catalytic pyrolysis of one non-edible oil seed Karanja was performed in a semi batch reactor. The pyrolytic liquid was separated as oil and aqueous layer with a yield of $33 \%$ and $22.17 \%$ by weight respectively. The oil was rich in hydrocarbon and thus termed as pyrolytic oil which can be used as fuel. Catalytic pyrolysis was carried with $\mathrm{CaO}, \mathrm{Al}_{2} \mathrm{O}_{3}$ and $\mathrm{Kaolin}$ at various feed to catalytic ratios. Catalytic pyrolysis confirmed that lower feed to catalyst ratio $(8: 1)$ increased the yield. In terms of pyrolytic oil yield, the catalysts $\mathrm{Al}_{2} \mathrm{O}_{3}$ and Kaolin proved to be better than $\mathrm{CaO}$ whereas all the catalysts resulted in better quality of pyrolytic oil in comparison with thermal pyrolysis. The composition analysis provided the evidence that the acids produced during thermal pyrolysis of Karanja seed got converted to esters during catalytic pyrolysis.

Biomass feedstocks, such as wood, agricultural and forest residues, energy plants, urban and solid industrial wastes, lumber and municipal wastes have attracted great attention as renewable energy sources in the worldwide. Cirsium is one of the largest genera within the family Asteraceae and comprises approximately 250 species, distributed in Eurasia, North America, northern and eastern Africa, and growing mainly in wet wastelands and steppes [17]. It is a genus of perennial and biennial flowering plants known commonly as thistles. They are known for their effusive flower heads, usually purple, rose or pink, also yellow or white. They have erect stems and prickly leaves, with a characteristic enlarged base of the flower. In Turkey, Cirsium is represented by 61 species. Endemic and non-endemic species are mainly distributed in the east and north-east Anatolia [18].

Turkey has many sources of renewable energies such as hydropower, geothermal, solar or wind, biomass. Among them, biomass is used less than others as a potential of bio-oil or chemicals. However, Turkey has high potential of agricultural renewable source with diverse crops production in 25 million hectares of arable land. Numerous types of plants grow in the lands of Turkey and they can be evaluated as a source of biomass for production of clean energy or chemicals $[19,20]$. One of them is Cirsium yildizianum which grows in east parts of Turkey. Its stalks go dormants in autumn and have no value in terms of industrial respect. In the present study, the conventional pyrolysis of Cirsium yildizianum was conducted at three different temperatures (350, 450 and $550{ }^{\circ} \mathrm{C}$ ) without and with boron minerals as catalyst. The catalysts used in this study were tincal $\left(\mathrm{Na}_{2} \mathrm{~B}_{4} \mathrm{O}_{7} \cdot 10 \mathrm{H}_{2} \mathrm{O}\right)$, colemanite $\left(\mathrm{CaB}_{3} \mathrm{O}_{4}(\mathrm{OH})_{3} \cdot \mathrm{H}_{2} \mathrm{O}\right)$ and ulexite $\left(\mathrm{NaCaB}_{5} \mathrm{O}_{6}(\mathrm{OH})_{6} \cdot 5\left(\mathrm{H}_{2} \mathrm{O}\right)\right)$ minerals of boron. Effects of pyrolysis parameters such as temperature and catalyst were investigated. However, the main objective of the study was to investigate the effect of catalysts on product yields and to improve the fuel properties of bio-oils with the use of catalyst. The experiments and methodology used in present study was similar to that of published in previous work [21]. Another objective of the study was to compare how the biochemical composition of the starting raw material affected the product yields and the properties of resulting bio-oils. In this regard, the chemical compositions of bio-oils were determined by using GCMS and FT-IR. The elemental analysis of bio-oils was also conducted. 


\section{MATERIALS AND METHODS}

\subsection{Materials}

Cirsium yildizianum samples, which are naturally grown in East Anatolia were collected from Bingöl region (geographical coordinates: $38^{\circ} 53^{\prime} 10^{\prime \prime}$ North, $40^{\circ} 30^{\prime}$ 6" East) in Turkey, in June 2013. The samples were dried in open air and ground in Perten Instruments LM120 mill to pass through a screen of $0.425 \mathrm{~mm}$ aperture and extracted with petroleum ether (b.p. $40-60^{\circ} \mathrm{C}$ ) in a Soxhlet extractor for $6 \mathrm{~h}$.

Before starting pyrolysis experiments, ultimate and proximate analysis of the Cirsium yildizianum were performed to determine the compositon and evaluate the potential for production of bio-oil. Ultimate analysis of the sample was performed using an Elemental analyzer (LECO CHNS-932). Tappi Test methods [22] were used to determine the main characteristics of the Cirsium yildizianum. Lignin was determined according to Tappi T222. Hollocellulose and cellulose contents were determined using the chloride method [23] and Tappi T202 method respectively. Ash and moisture contents were determined by Tappi T211 and Tappi T264 respectively. Higher heating value (HHV) was calculated by using Dulong's Formula. Fourier transform infrared (FT-IR) analysis of the raw material was also carried out using a Varian model Scimitar 2000 to identify structural groups using potassium bromide as transparent pellets. Table 1 gives the results of ultimate and proximate analyses of Cirsium yildizianum. Figure 1 shows the FT-IR spectra of raw material. The raw Cirsium yildizianum was characterized by FT-IR in the middle region including the wave numbers between $4000-550 \mathrm{~cm}^{-1}$. The aim of the analysis was to identify the functional groups of the raw material. According to literature [24-28], the bands in the spectra of raw material proves that it is mainly composed of lignin, cellulose and hemicelluloses. The band at $3337.11 \mathrm{~cm}^{-1}$ is formed by the hydroxyl group of lignin in Cirsium yildizianum. The absorption at wave number of $1733.83 \mathrm{~cm}^{-1}$ is the characteristic of xylans of hemicellulose. The absorption peaks at about 2922.03 and $1369.79 \mathrm{~cm}^{-1}$ are the characteristics of cellulose. In general, the spectrum of lignin gives the similar absorption peaks. The absorptions at $2922.03,1600.82$ and $1027.38 \mathrm{~cm}^{-1}$ represent the lignin, especially the sharp peak at $1027.38 \mathrm{~cm}^{-1}$ is due to the ether bonds present in raw material.
Table 1: Main Characteristics of the Cirsium yildizianum

\begin{tabular}{|c|c|}
\hline Components & \\
\hline Moisture (\%) & 5.24 \\
\hline \multicolumn{2}{|l|}{ Proximate analysis $^{a}(\%)$} \\
\hline Ash & 4.81 \\
\hline Lignin & 29.79 \\
\hline Cellulose & 42.83 \\
\hline Hemicellulose & 16.71 \\
\hline Holocellulose & 59.54 \\
\hline $\begin{array}{c}\text { Soxhelet extractives }\left(40-60{ }^{\circ} \mathrm{C} \text { petroleum }\right. \\
\text { ether) }\end{array}$ & 0.62 \\
\hline \multicolumn{2}{|l|}{ Ultimate analysis $^{b}(\%)$} \\
\hline Carbon & 44.87 \\
\hline Hydrogen & 6.32 \\
\hline Nitrogen & 0.45 \\
\hline Oxygen $^{c}$ & 48.36 \\
\hline $\mathrm{H} / \mathrm{C}$ molar ratio & 1.69 \\
\hline $\mathrm{O} / \mathrm{C}$ molar ratio & 0.81 \\
\hline Empirical Formula & $\mathrm{CH}_{1.69} \mathrm{~N}_{0.008} \mathrm{O}_{0.81}$ \\
\hline \multicolumn{2}{|l|}{ Higher Heating Value (MJ/kg) } \\
\hline Dulong's formula & 15.57 \\
\hline
\end{tabular}

${ }^{a}$ Weight percentage on dry basis. ${ }^{b}$ Weight percentage on dry and ash free basis. ${ }^{\mathrm{C}} \mathrm{By}$ difference.

Before exprerimental study, thermal behaviour of the raw material was also investigated by thermogravimetric (TG) and differential thermal analysis (DTA). The thermogravimetric weight loss and the corresponding derivative curves are given in Figure 2. When TG curve is examined, approximately $5 \%$ weight loss until $110^{\circ} \mathrm{C}$ shows the amount of moisture content of raw material which is close to the value given in Table 1. Hemicelluloses and cellulose of the raw material, the main components of biomass start to decompose at $235.1{ }^{\circ} \mathrm{C}$. The temperature at which the maximum decomposition occurs was approximately determined as $340.7{ }^{\circ} \mathrm{C}$. All of the components (hemicelluloses, cellulose and lignin) of the raw material decompose very rapidly at this temperature reaching a maximum weight loss. The maxiumum weight loss $(71.4 \%)$ of the raw material was occured between 235.1 and $348.7{ }^{\circ} \mathrm{C}$. After $348.7^{\circ} \mathrm{C}$, rate of decomposition gradually decreases and gets a minimum approximately at $550{ }^{\circ} \mathrm{C}$. After $550{ }^{\circ} \mathrm{C}$, difference is weight loss gets smaller and becomes almost zero at $750{ }^{\circ} \mathrm{C}$. The amount of substances left behind after $750{ }^{\circ} \mathrm{C}$ is the percentage of ash which was determined as $4.81 \%$ by weight from Tappi T211. 


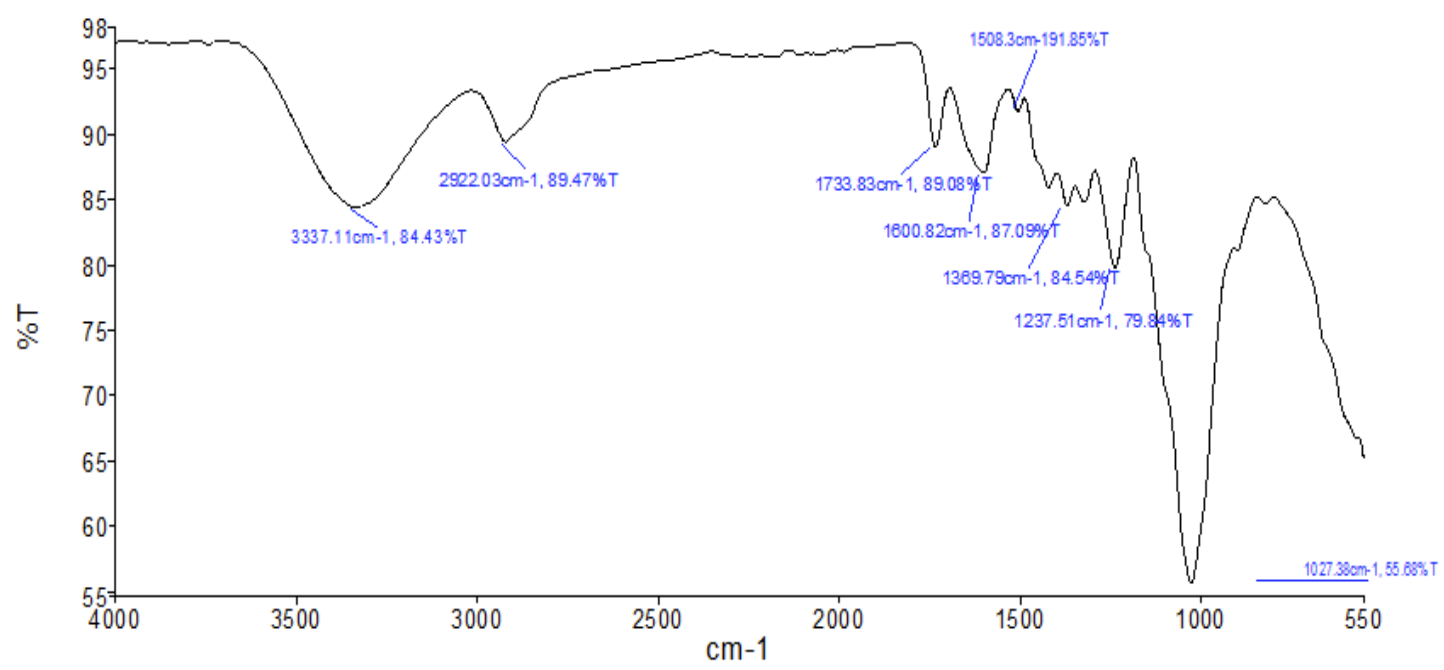

Figure 1: FT-IR spectra of raw material (Cirsium yildizianum).

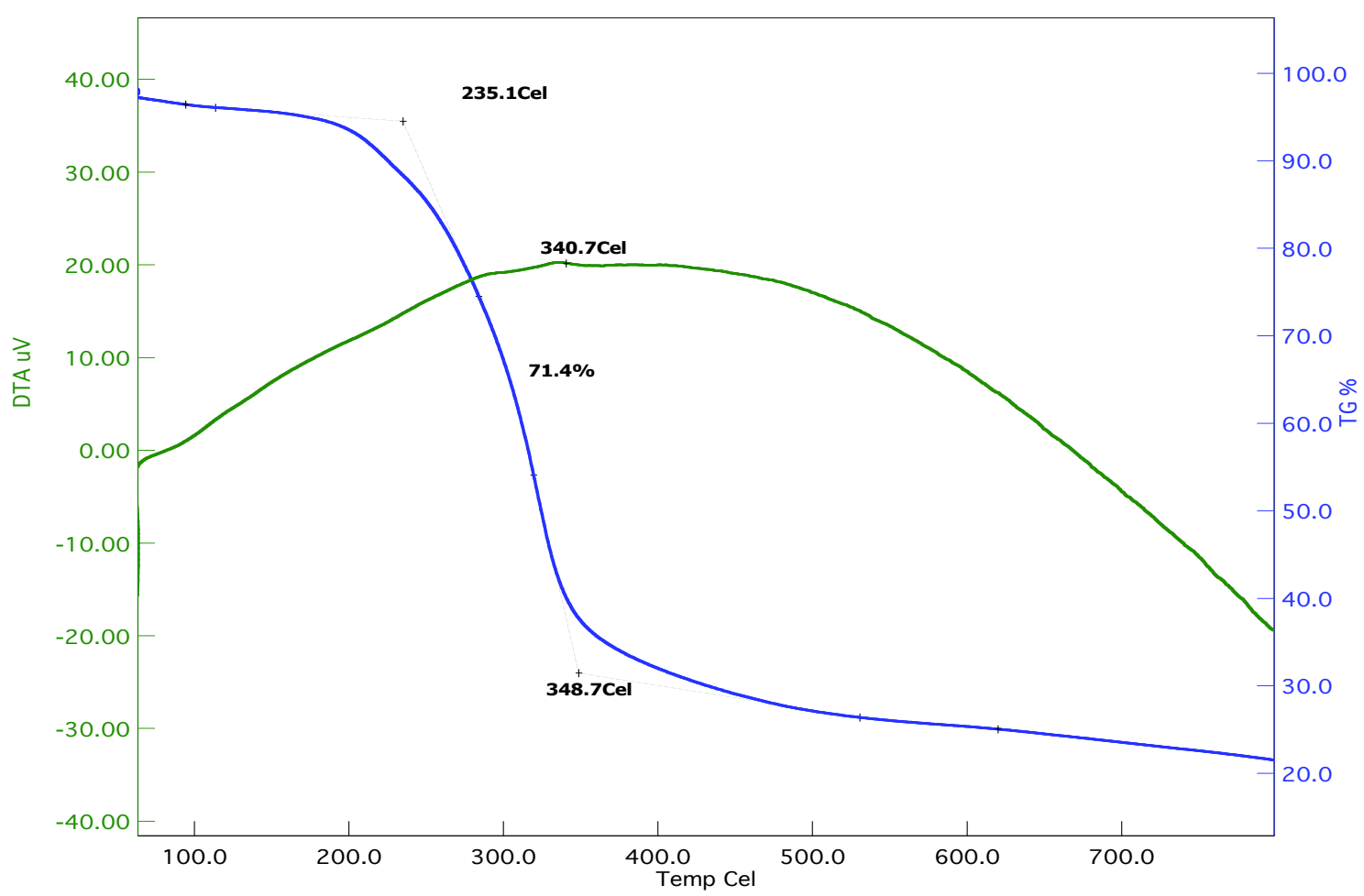

Figure 2: TG-DTA curves of Cirsium yildizianum obtained under nitrogen atmosphere.

\subsection{Experimental Procedure}

The slow pyrolysis experiments were performed in a fixed-bed tubular reactor made of stainless steel with dimensions of $70 \mathrm{~mm}$ inner diameter, $10 \mathrm{~mm}$ outer diameter and $200 \mathrm{~mm}$ height equipped with connection for inert gas input. Schematic diagram for the fixed-bed tubular reactor system is given in Figure 3. In each trial, $20 \mathrm{~g}$ of raw material was put inside the reactor, closed tightly with connections for inert gas entry and products output pipe connected to liquid product collecting bottles. The reactor was heated externally by an electric furnace and the temperature is controlled by a $\mathrm{NiCr}-\mathrm{Ni}$ thermocouple placed inside the bed. The liquid collecting bottles were cooled to $-10{ }^{\circ} \mathrm{C}$ using frozen salt-ethanol and water mixture and the temperature kept constant as $-10{ }^{\circ} \mathrm{C}$ until no more gas is evolved from pyrolysis process. The gas product was discharged into a chimney through a hose and a fan. During the whole pyrolysis process, nitrogen gas is circulated to provide the inert atmosphere inside the reactor. By inputing the desired variables to the control 


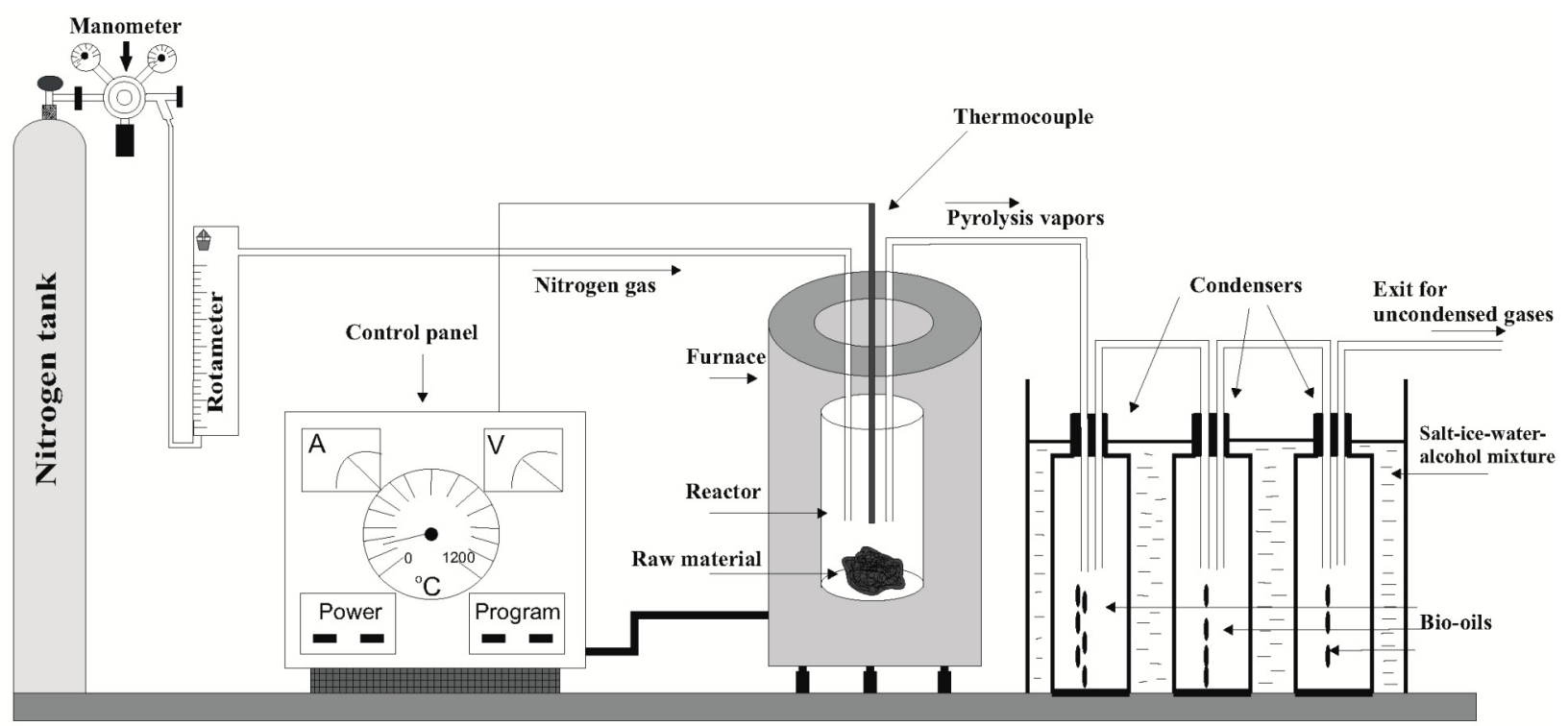

Figure 3: Schematic diagram for the fixed-bed tubular reactor system.

unit in heater, pyrolysis experiments at different conditions have been performed.

The pyrolysis experiments were performed in two series. In the first one, experiments without catalyst at three different temperatures $\left(350,450\right.$ and $\left.550^{\circ} \mathrm{C}\right)$ with a constant heating rate $50{ }^{\circ} \mathrm{C} / \mathrm{min}$ were carried out to investigate the effect of temperature. The condensed liquid products which contain an aqeous (pyrolignic acid) and oil (pyrolytic oil) phase were collected in bottles. They were washed with dichloromethane, put in a separating funnel and separated from each other by decantation. Pyrolytic oil or bio-oil is dried with anhydrous sodium sulphate and recovered by evaporating the solvent in a rotary evaporator at temperature of $313 \mathrm{~K}$ and reduced pressure of $11 \mathrm{kPa}$ and its yield (liquid) was calculated. After cooling the pyrolysis reactor, the amount of solid (bio-char) left behind was removed and weighed. The conversion of raw material to liquid and gasesous products was calculated by subtraction of amount of solid (bio-char) left behind in the reactor. The amount of gas evolved was calculated by subtraction of amount of solid and liquid products from 20, the amount of initial raw material. The following equations were used to calculate the conversion and product yields.

Coversion $(\%)=\frac{\left(\mathrm{W}_{\text {Biomass,db }}-\mathrm{W}_{\text {Solid,db }}\right)}{\mathrm{W}_{\text {Biomass,db }}} \times 100$

Liquid yield $(\mathrm{wt} \%)=\frac{\left(\mathrm{W}_{\text {Liquid }}\right)}{\mathrm{W}_{\text {Biomass,db }}} \times 100$
Solid yield $(w t \%)=\frac{\left(\mathrm{W}_{\text {Solid,db }}\right)}{\mathrm{W}_{\text {Biomass,db }}} \times 100$

Gas yield $(w t \%)=100 \%$ - liquid yield $(w t \%)$-solid yield (wt \%) (4)

where $\mathrm{W}_{\text {Biomass, db }}$ and $\mathrm{W}_{\text {Solid, db }}$ are the weights of initial biomass and remaining solid (bio-char) respectively on dry basis.

In the second group of experiments, three boron minerals (tincal, colemanite and ulexite) with $10 \%$ by weight were added to reactor and pyrolysis experiments at the same temperatures used in noncatalytic runs were performed to investigate the effect of catalyst on product yields. Upon completion of all experiments, the product yields were calculated and expressed on dry and ash free basis.

\section{RESULTS AND DISCUSSION}

\subsection{Effect of Temperature and Catalyts on Product Yields}

The conversion and distribution of products obtained by pyrolysis of Cirsium yildizianum at different temperatures with and without catalyst is given in Table 2. The effect of temperature and catalysts on conversion and product yields are given in Figures 4-7. The data given in the Figures 4-7. were obtained from the experimental runs given in Table 2. Figures 4-7 show that temperature had a positive effect on conversion, bio-oil and gas product yields at all temperatures. Table 1 shows that when temperature 
Table 2: The Conversion ${ }^{a}$ and Distribution of Products Obtained by Pyrolysis of Cirsium yildizianum at Different Temperatures with and without Catalyst.

\begin{tabular}{|c|c|c|c|c|}
\hline Temperature & Conversion (\%) & Solid (\%) & Liquid (\%) & Gas (\%) \\
\hline \multicolumn{5}{|c|}{$350^{\circ} \mathrm{C}$} \\
\hline Tincal & 71.13 & 28.87 & 38.45 & 32.68 \\
\hline Colemanite & 74.26 & 25.74 & 39.94 & 34.32 \\
\hline \multicolumn{5}{|c|}{$450^{\circ} \mathrm{C}$} \\
\hline No catalyst & 73.79 & 26.21 & 38.54 & 35.25 \\
\hline Tincal & 74.41 & 25.59 & 39.61 & 34.80 \\
\hline Colemanite & 77.52 & 22.48 & 40.45 & 37.07 \\
\hline Tincal & 77.08 & 22.92 & 39.80 & 37.28 \\
\hline Colemanite & 77.78 & 22.22 & 40.62 & 37.16 \\
\hline Ulexite & 76.34 & 23.66 & 40.21 & 36.13 \\
\hline
\end{tabular}

${ }^{a}$ Mass fraction percentage of the dry and ash free feedstock.

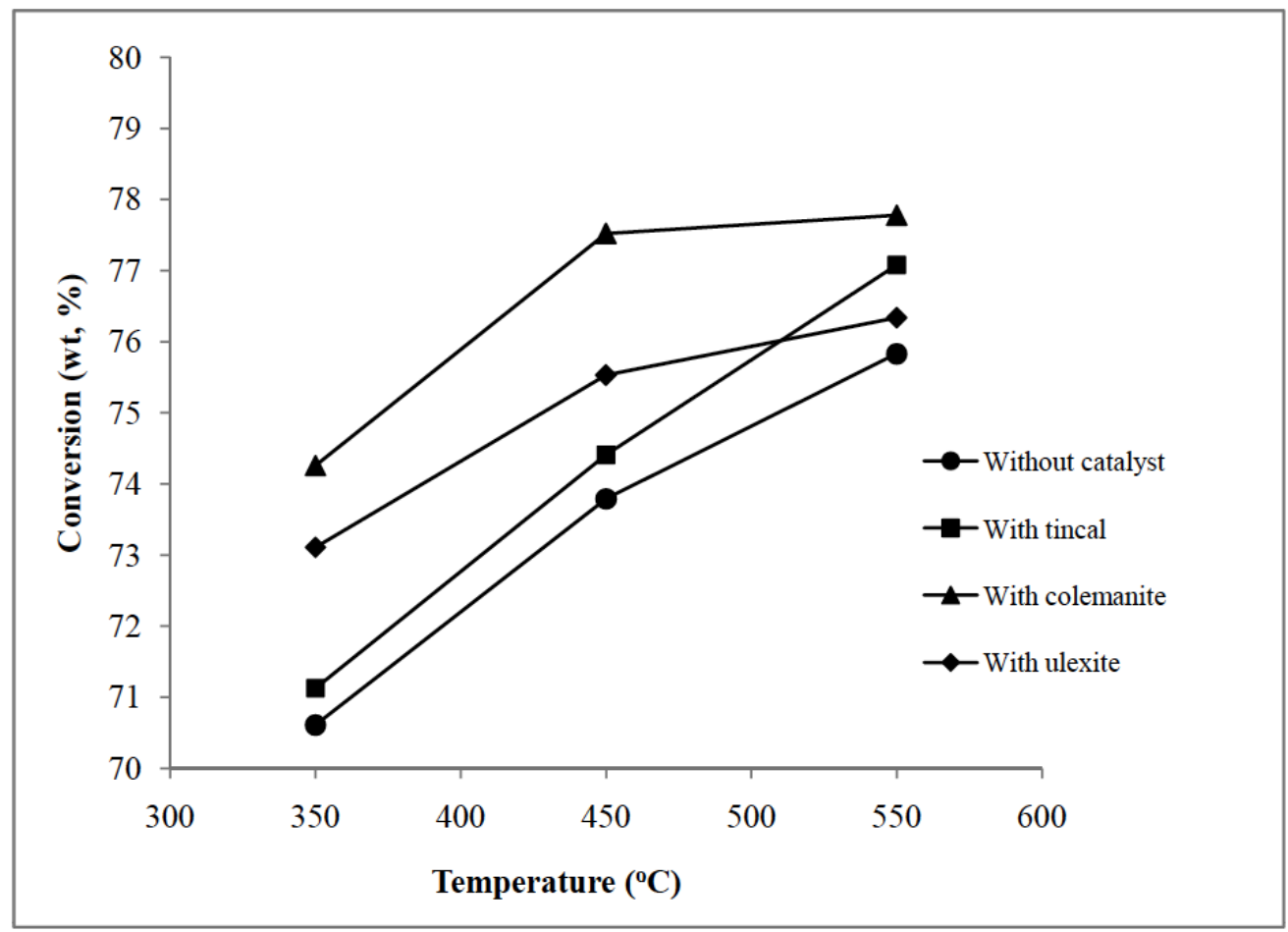

Figure 4: Effect of temperature and catalyst on conversion.

was increased from 350 to $550{ }^{\circ} \mathrm{C}$, conversion was increased from $70.61 \%$ to $75.83 \%$ in the non-catalytic runs; from $71.13 \%$ to $77.08 \%$ in the presence of tincal. Bio-oil yields were increased from $37.23 \%$ to
$38.54 \%$ when temperature was increased from 350 to $450{ }^{\circ} \mathrm{C}$. Further increase in temperature to $550{ }^{\circ} \mathrm{C}$ did not affect the bio-oil yield (38.86\%) considerably. Similar results were obtained in the catalytic runs. The 


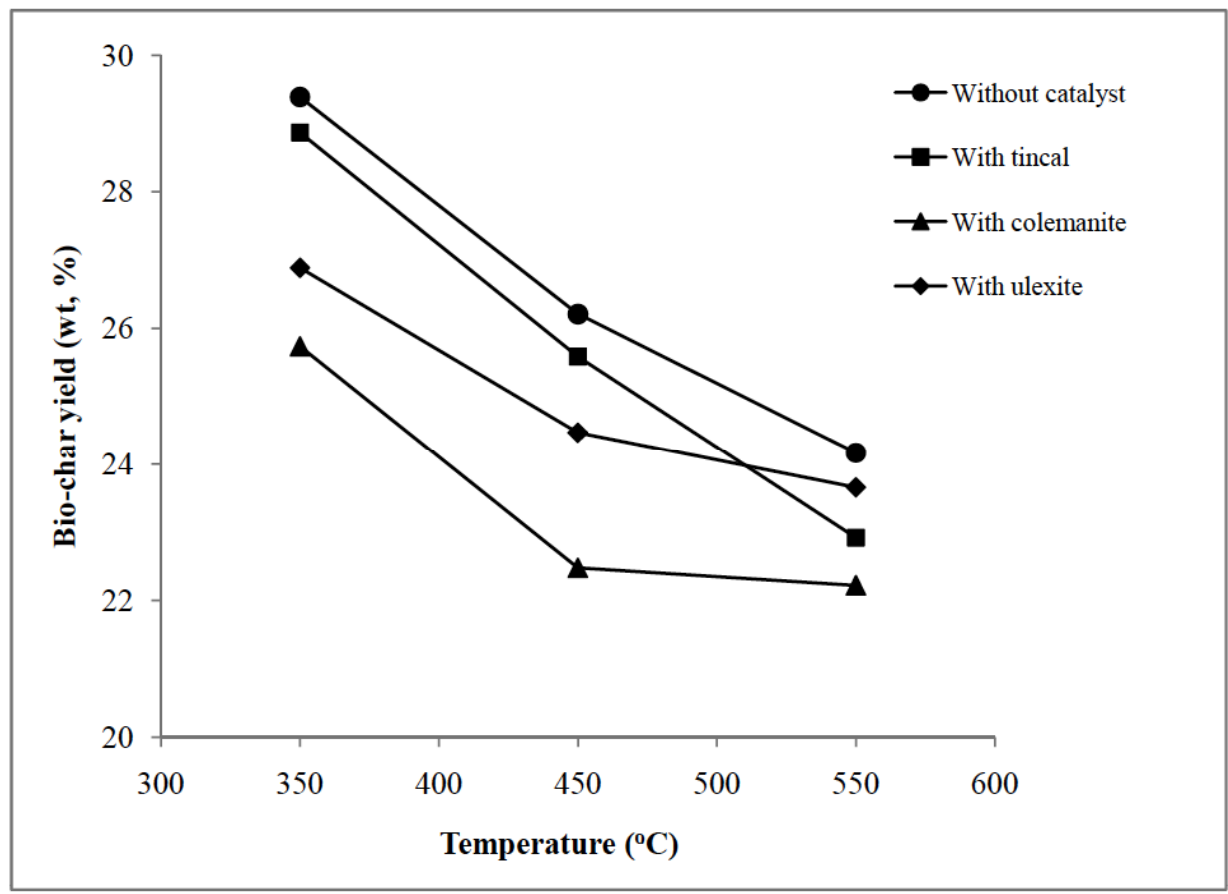

Figure 5: Effect of temperature and catalyst on bio-char yields.

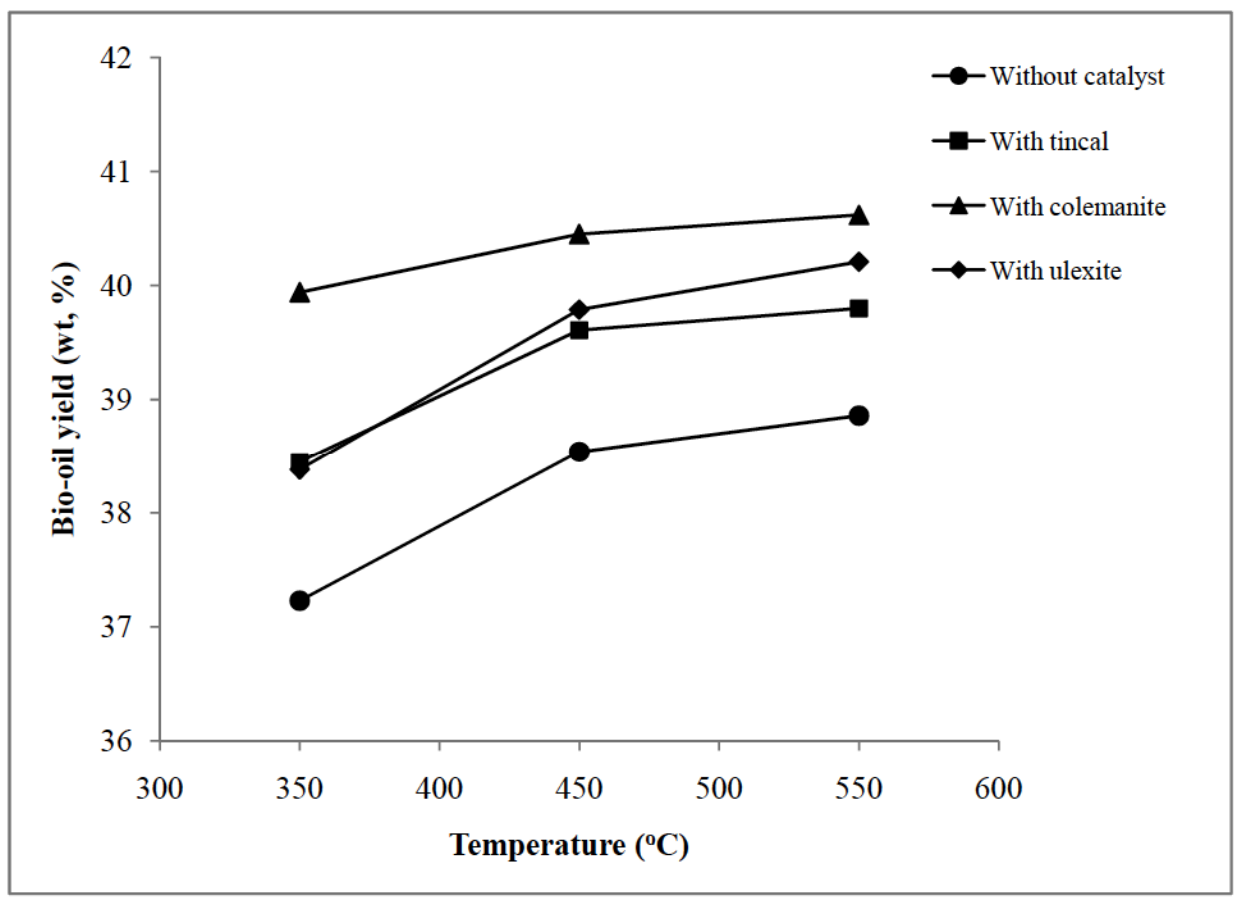

Figure 6: Effect of temperature and catalyst on bio-oil yields.

highest bio-oil yield of $40.62 \%$ was obtained at $550{ }^{\circ} \mathrm{C}$ in the presence of colemanite in the catalytic runs. The gas yields were increased steadily with increasing temperature. When temperature was increased from 350 to $550{ }^{\circ} \mathrm{C}$, the gas yields were increased from $33.38 \%$ to $36.97 \%$ in the non-catalytic runs. The reasons for increasing of gas yields at higher temperatures are due to secondary cracking of the oil vapors and secondary decomposition of the bio-chars forming non-condensable gaseous substances contributing an increase in gas products $[29,30]$. Biochar yields were decreased constantly with increasing the pyrolysis temperature, because of greater primary decomposition of the biomass or secondary decomposition of the char residue, leading the higher conversions with increasing temperature. When 


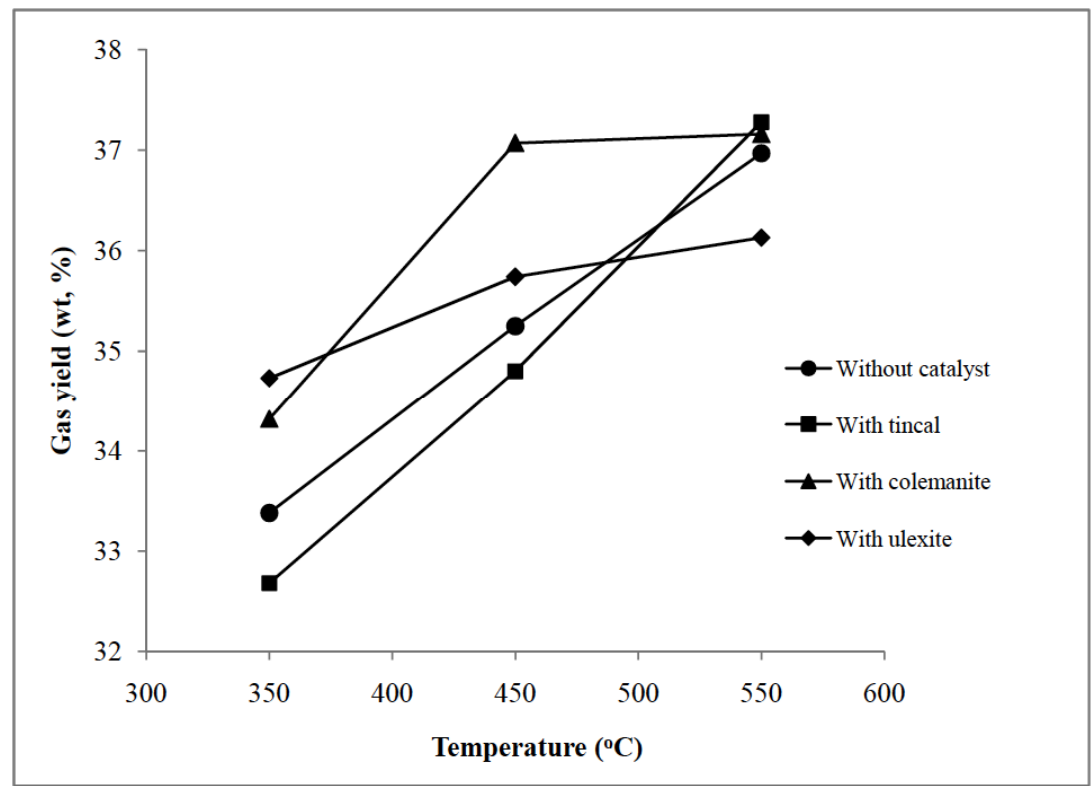

Figure 7: Effect of temperature and catalyst on gas yields.

temperature was increased from 350 to $550{ }^{\circ} \mathrm{C}$, biochar yields were decreased from $29.39 \%$ to $24.17 \%$ in the non-catalytic runs. Similar trend was followed in the catalytic runs.

Many researchers studied biomass pyrolysis parameters and found that temperature was the most effective on product yields [31-33]. According to a recent study, the pyrolysis of apricot kernel shell was performed for determining the main characteristics and quantities of liquid and solid products. Experiments were carried out in a static atmosphere with heating rates of $10{ }^{\circ} \mathrm{C} / \mathrm{min}$ and $50{ }^{\circ} \mathrm{C} / \mathrm{min}$, pyrolysis temperatures of $400,450,500$ and $550{ }^{\circ} \mathrm{C}$ and sweep gas flow rates of $50-200 \mathrm{~cm}^{3} / \mathrm{min}$. The maximum bio-oil (26.3\%) and char (35.2\%) yields were obtained at 500 ${ }^{\circ} \mathrm{C}$ and $400{ }^{\circ} \mathrm{C}$ respectively [34]. In a recent study [35], conventional pyrolysis of Niger seed was investigated in a semi batch reactor with and without the presence of catalyst $\left(\mathrm{Al}_{2} \mathrm{O}_{3}, \mathrm{CaO}\right.$, Kaolin). Thermal pyrolysis yielded maximum $34.5 \%$ of oil (by weight basis) at 550 ${ }^{\circ} \mathrm{C}$ temperature. The yield and fuel properties of thermal and catalytic pyrolytic oils were compared. It was found that the presence of catalysts decreased the oil yield marginally whereas enhanced the fuel properties compared with thermal pyrolysis.

Catalyic pyrolysis experiments were carried out using same heating rate of $50{ }^{\circ} \mathrm{C} / \mathrm{min}$ at the same temperatures used in non-catalytic runs to determine the effect of boron catalysts (tincal, colemanite and ulexite) on product yields. As seen from Figures 4-7, catalysts have effected the product yields differently. All catalysts have increased the conversions and liquid yields with increasing temperature compared to noncatalytic runs. Among them, colemanite was the most effective and tincal was the least effective. The highest conversion of $77.78 \%$ was achieved in the presence of colemanite $(10 \%)$ in the catalytic runs at $550{ }^{\circ} \mathrm{C}$. The liquid yield, which was $38.86 \%$ without catalyst, reached the maximum value of $40.62 \%$ in the presence of colemanite at $550{ }^{\circ} \mathrm{C}$. The gas yields were increased with temperature while bio-char yields were decreased steadily in both catalytic and non-catalytic runs at all temperatures. For example, the gas yields were increased from $34.73 \%$ to $36.13 \%$ in the catalytic runs with ulexite when temperature was increased from 350 to $550{ }^{\circ} \mathrm{C}$. Similar results were obtained with tincal and colemanite.

The liquid product obtained in pyrolysis contains an aqueous phase and bio-oil or oil phase which is generally called as pyrolytic liquid. It is a black liquid containing highly oxygenated compounds used as boiler fuel in power stations for heat production. If it is intended to be used as transportation fuel, it should be upgraded first by hydrodeoxygenation to produce aromatics or hydrocarbons, or catalytic cracking by using zeolite to produce light aromatic hydrocarbons and light alkanes. There are many reports of pyrolysis and liquefaction regarding the effect of catalysts on product yields in literature [36-38]. In recent years, there have been so many pyrolysis studies regarding the effect of catalysts on product distribution of biomass samples. Addition of a catalyst can make significant changes on the yields and properties of 
pyrolysis products. In most studies, addition of catalyst has increased the liquid yields while in some studies, it had negative effect and decreased the liquid product yields. Similar results were obtained for solid and gas yields which were either increased or decreased by adding catalyst [39-41]. One of the recent studies in which potassium carbonate was used as catalyst carried out by Wang et al. [42]. They have performed the catalytic pyrolysis of pine wood in a fixed-bed reactor heated slowly from room temperature to $700{ }^{\circ} \mathrm{C}$ under a stream of purging argon gas. Potassium carbonate demonstrated a stronger catalytic effect for decomposition of hemicellulose, cellulose and lignin constituents, leading to the reduced yield of liquid product in conjunction with the increased yields of gaseous and char products because of the promoted secondary reactions of liquid product.

\subsection{Characterization of Bio-Chars and Bio-Oils by Elemental, FT-IR and GC-MS Analysis}

The produced bio-chars and bio-oils at 350 and 550 ${ }^{\circ} \mathrm{C}$ were analyzed and characterized by chromatographic and spectroscopic techniques using elemental, FT-IR and GC-MS. Elemental analysis was performed with LECO CHNS 932 analyser and infrared analysis with a PerkinElmer Spectrum 100 Spectrophotometer. The GC-MS analysis was performed on Agilent GC-MS
7890A/5975C series (Agilent Technologies, Santa Clara, CA). The column (HP -INNOWAX, length: 60m., I.D.: $0,250 \mathrm{~mm}$, film: $0,25 \mu \mathrm{m}$ and temperature limits: from $40{ }^{\circ} \mathrm{C}$ to $260{ }^{\circ} \mathrm{C}$ ) and injector temperatures were the same as those for GC. The carrier gas was helium at a flow rate of $1.7 \mathrm{ml} / \mathrm{min}$. Samples of $1 \mu \mathrm{L}$ were injected with a split ratio of 1:30. The GC oven temperature program was as follows: started at $40{ }^{\circ} \mathrm{C}$; held for $10 \mathrm{~min}$, raised from $40{ }^{\circ} \mathrm{C}$ to $200{ }^{\circ} \mathrm{C}$ with 5 ${ }^{\circ} \mathrm{C} / \mathrm{min}$ heating rate; held for $15 \mathrm{~min}$, raised to $240{ }^{\circ} \mathrm{C}$ with $10{ }^{\circ} \mathrm{C} / \mathrm{min}$ heating rate; held for $15 \mathrm{~min}$, raised to $260{ }^{\circ} \mathrm{C}$ with $10{ }^{\circ} \mathrm{C} / \mathrm{min}$ heating rate; held at this final temperature for $10 \mathrm{~min}$. The column was directly introduced into the ion source of an Agilent 5975 series mass selective detector operating with an electron impact (EI) ionization mode. Chemical constituents were identified by comparison of their retention indices with literature values $[43,44]$ and their mass spectral data with those from the W8N05ST.L, ADAMS.1 and Flavor3.L mass spectral databases.

The results of elemental analyses of bio-chars and bio-oils obtained at 350 and $550{ }^{\circ} \mathrm{C}$ are given in Tables 3 and 4 respectively. Compared to carbon and oxygen contents of the raw material, all of the products (biochars and bio-oils) from pyrolysis have higher carbon and lower oxygen contents in both non-catalytic and catalytic runs, and accordingly have higher calorific

Table 3: The Results of Elemental Analyses ${ }^{\mathrm{a}}$ of Bio-Chars Obtained at 350 and $550{ }^{\circ} \mathrm{C}$

\begin{tabular}{|c|c|c|c|c|}
\hline Temperature & Without catalyst & With tincal & With colemanite & With ulexite \\
\hline \multicolumn{5}{|c|}{$350^{\circ} \mathrm{C}$} \\
\hline Carbon & 64.21 & 63.21 & 67.16 & 67.63 \\
\hline Hydrogen & 3.75 & 3.94 & 3.88 & 3.42 \\
\hline Nitrogen & 0.49 & 0.44 & 0.48 & 0.44 \\
\hline Oxygen $^{\mathrm{b}}$ & 31.55 & 32.41 & 28.48 & 28.51 \\
\hline $\mathrm{H} / \mathrm{C}$ molar ratio & 0.70 & 0.74 & 0.69 & 0.60 \\
\hline $\mathrm{O} / \mathrm{C}$ molar ratio & 0.36 & 0.38 & 0.32 & 0.31 \\
\hline $\mathrm{HHV}(\mathrm{MJ} / \mathrm{kg})$ & 21.44 & 21.22 & 23.18 & 22.67 \\
\hline \multicolumn{5}{|c|}{$550^{\circ} \mathrm{C}$} \\
\hline Carbon & 70.23 & 72.34 & 73.53 & 71.04 \\
\hline Hydrogen & 3.85 & 3.73 & 3.67 & 3.90 \\
\hline Nitrogen & 0.35 & 0.34 & 0.38 & 0.38 \\
\hline Oxygen $^{b}$ & 25.57 & 23.59 & 22.42 & 24.68 \\
\hline $\mathrm{H} / \mathrm{C}$ molar ratio & 0.65 & 0.62 & 0.59 & 0.65 \\
\hline $\mathrm{O} / \mathrm{C}$ molar ratio & 0.27 & 0.24 & 0.23 & 0.26 \\
\hline $\mathrm{HHV}(\mathrm{MJ} / \mathrm{kg})$ & 24.70 & 25.59 & 26.12 & 25.20 \\
\hline
\end{tabular}

${ }^{a}$ Weight percentage on dry and ash free basis. ${ }^{\mathrm{b}} \mathrm{By}$ difference. 
Table 4: The Results of Elemental Analyses ${ }^{\mathrm{a}}$ of Bio-Oils Obtained at 350 and $550{ }^{\circ} \mathrm{C}$

\begin{tabular}{|c|c|c|c|c|}
\hline Temperature & Without catalyst & With tincal & With colemanite & With ulexite \\
\hline \multicolumn{5}{|c|}{$350^{\circ} \mathrm{C}$} \\
\hline Hydrogen & 7.02 & 7.17 & 7.41 & 7.11 \\
\hline Nitrogen & 0.74 & 0.62 & 0.57 & 0.73 \\
\hline $\mathrm{H} / \mathrm{C}$ molar ratio & 1.42 & 1.42 & 1.51 & 1.38 \\
\hline $\mathrm{O} / \mathrm{C}$ molar ratio & 0.42 & 0.39 & 0.43 & 0.37 \\
\hline $\mathrm{HHV}(\mathrm{MJ} / \mathrm{kg})$ & 24.21 & 25.05 & 24.55 & 25.67 \\
\hline \multicolumn{5}{|c|}{$550^{\circ} \mathrm{C}$} \\
\hline Oxygen $^{b}$ & 28.22 & 27.44 & 29.37 & 28.20 \\
\hline $\mathrm{H} / \mathrm{C}$ molar ratio & 1.38 & 1.40 & 1.39 & 1.43 \\
\hline $\mathrm{O} / \mathrm{C}$ molar ratio & 0.33 & 0.32 & 0.35 & 0.33 \\
\hline $\mathrm{HHV}(\mathrm{MJ} / \mathrm{kg})$ & 27.11 & 27.69 & 26.39 & 27.36 \\
\hline
\end{tabular}

${ }^{a}$ Weight percentage on dry and ash free basis. ${ }^{b}$ By difference.

values. As seen in Tables $\mathbf{3}$ and $\mathbf{4}$, the calorific values of bio-chars and bio-oils were higher than $21.22 \mathrm{MJ} / \mathrm{kg}$ and $24.21 \mathrm{MJ} / \mathrm{kg}$ respectively, in comparison with the low calorific value $(15.57 \mathrm{MJ} / \mathrm{kg})$ of the raw material.

FT-IR spectrums of bio-chars obtained at $550{ }^{\circ} \mathrm{C}$ are given in Figure 8. Compared with raw material, there have been significant changes in the FT-IR spectrum as a result of pyrolysis. The $\mathrm{O}-\mathrm{H}$ stretching vibration band at $3337 \mathrm{~cm}^{-1}$ has been dissappeared in bio-chars obtained at $550{ }^{\circ} \mathrm{C}$. During the pyrolysis process, oxygen was removed from raw material. This causes the phenolic and aromatic structures to crack, producing carbonaceous solid products. The FT-IR spectrums of bio-chars were similar to each other. The C-C stretching vibrations between 1300 and $1600 \mathrm{~cm}^{-1}$ indicate the presence of aromatics and alkanes. FT-IR spectrums indicate that the bio-chars obtained from pyrolysis were mainly composed of aromatic and aliphatic compounds.

FT-IR spectrums and total ion chromatograms of bio-oils (without and with catalyst) obtained at $550{ }^{\circ} \mathrm{C}$ are given in Figures 9-10 respectively. The list of the compounds identified by GC-MS in Figure $\mathbf{1 0}$ is given in Table 5. As seen in Table 5, bio-oils contain various types of compounds with different molecular structures and molecular weights, produced from decomposition of hemicellulose, cellulose and lignin in raw material. Bio-oils identified by GC-MS were consist of complex mixtures of organic compounds from wide variety of chemical groups. These compounds can be mainly grouped into three classes: aromatics, oxygenated and nitrogenated compounds. Aromatics include benzene and derivatives, furans, phenols and derivatives. Oxygenated compounds were composed of aldehydes, ketones, esters and carboxylic acids. Amines and amides such as benzothiazole, cyanamide, pyrroline and imidazole were identified as nitrogenated compounds.

In accordance with the previous studies [45-49], biooils were composed of mainly aldehydes, ketones and phenolics and their derivatives. Most of these compounds were formed from the decomposition of lignin and the others were from cellulose. The phenolics were consists of phenols, methoxy phenols, alkyl phenols, guaiacol and cresols. As pyrolytic liquids are used not only as a fuel in engines or boilers, but also as a valuable organic chemicals, phenolics can be considered as one of them for their commercial value. During pyrolysis of lignocellulosic biomass, hemicelluloses decompose first $\left(200-280{ }^{\circ} \mathrm{C}\right)$ forming the acidic compounds such as formic and acetic acid. On the other hand, decomposition of cellulose (240$350{ }^{\circ} \mathrm{C}$ ) produces levoglucosan as a primary 
Bio-Oil Production from Cirsium yildizianum through Pyrolysis

Journal of Applied Solution Chemistry and Modeling, 2014, Volume 3, No. 3

145

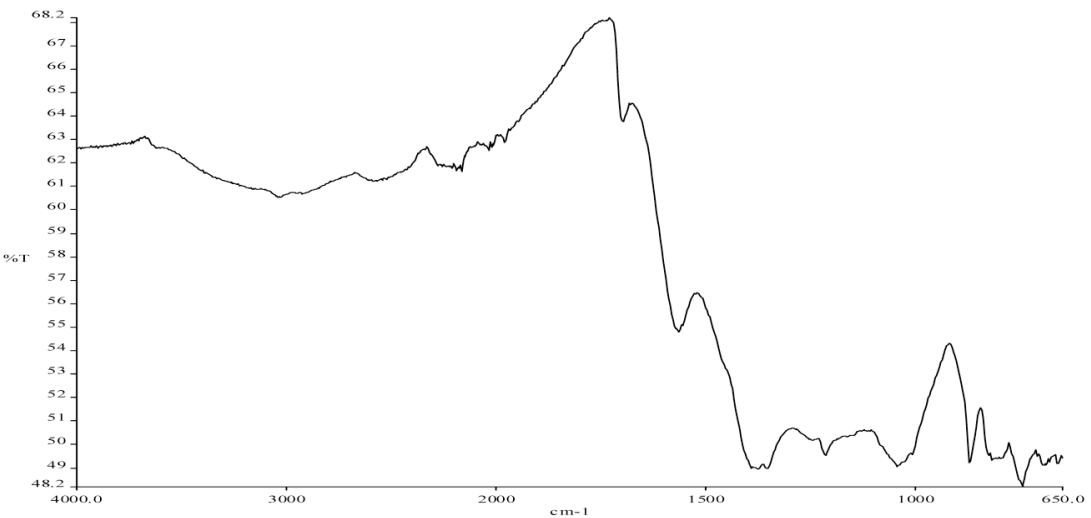

a)

Without catalyst

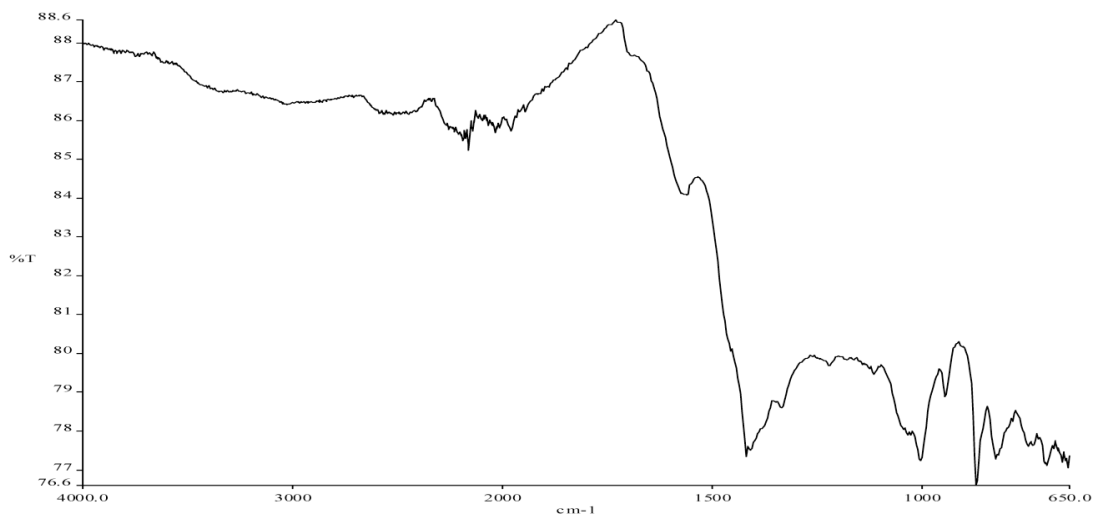

b) With tincal

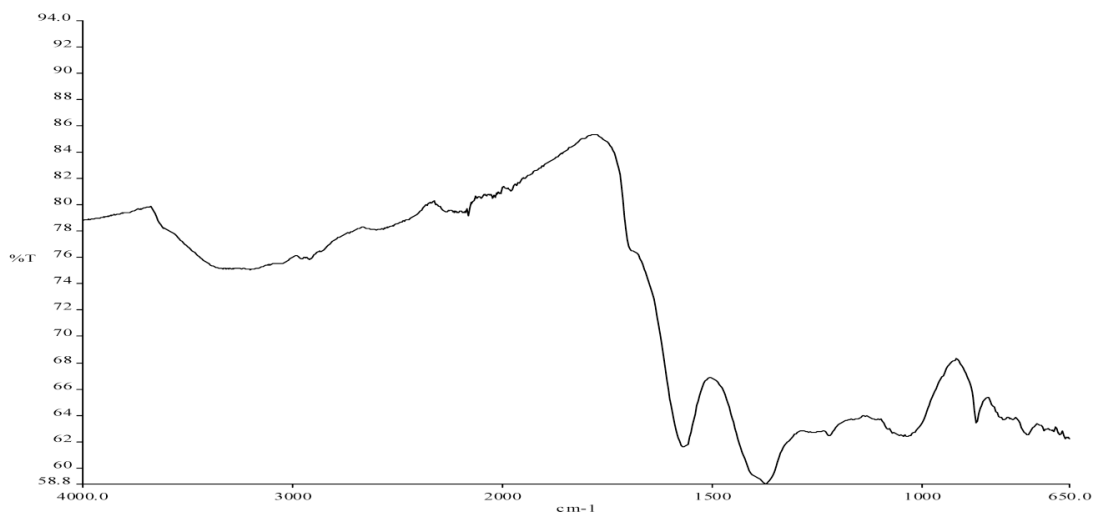

c) With colemanite

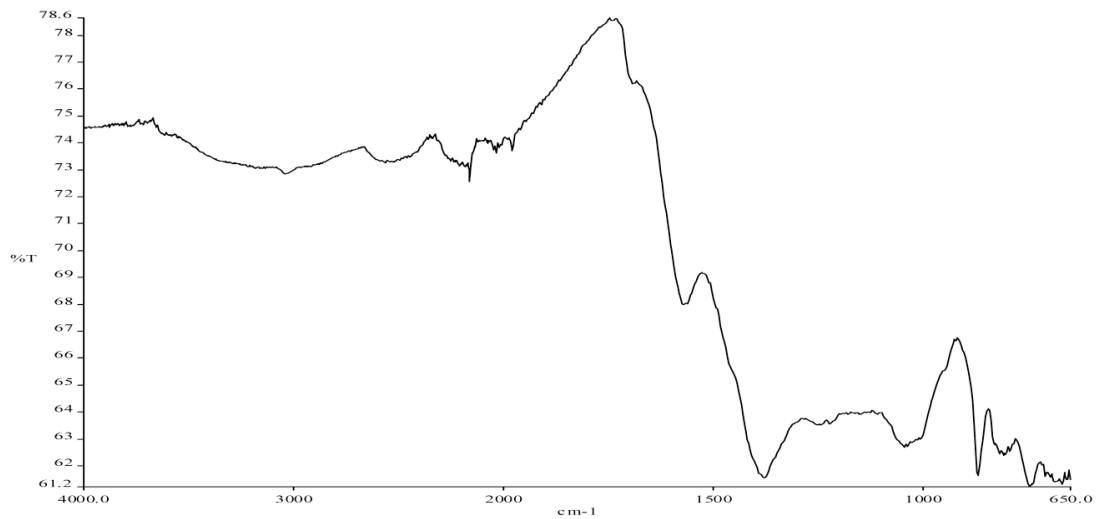

d) With ulexite

Figure 8: FT-IR spectrum of bio-chars obtained at $550{ }^{\circ} \mathrm{C}$. 


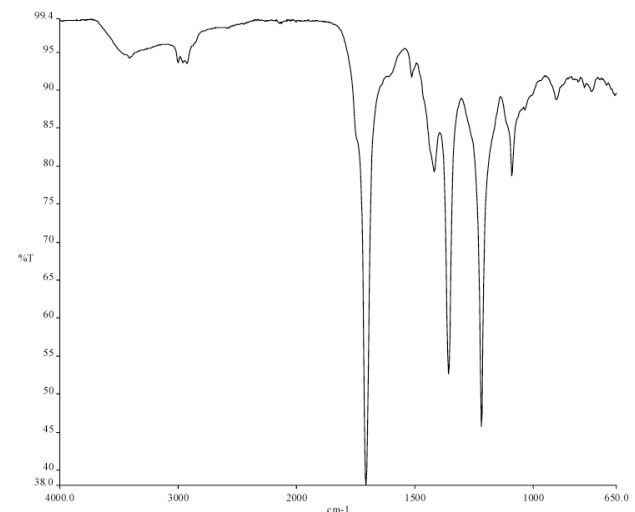

a) Without catalyst

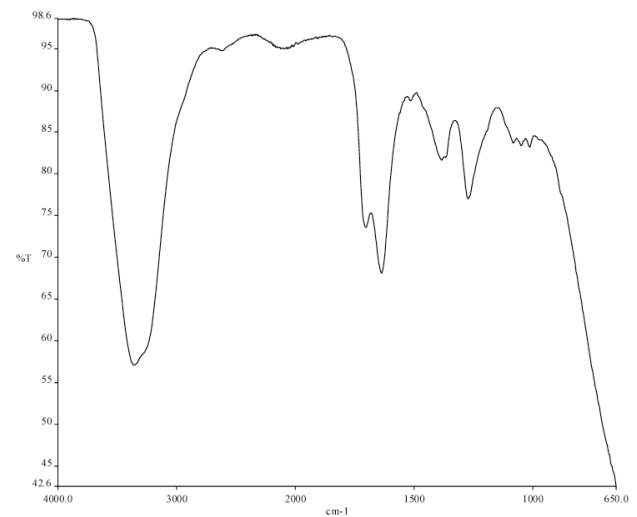

b) With tincal

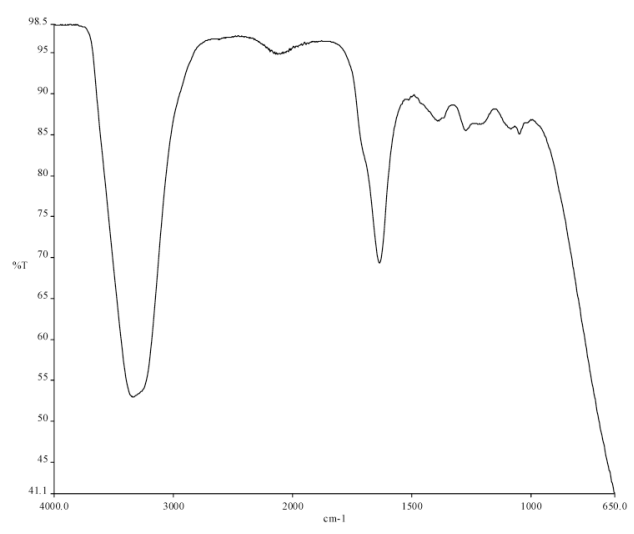

c) With colemanite

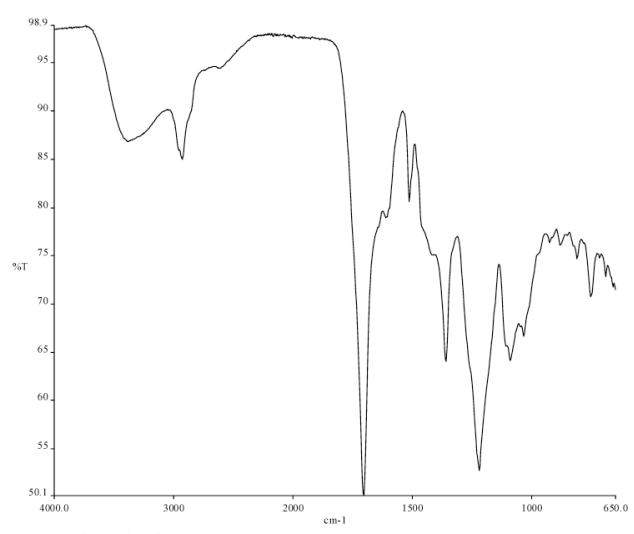

d) With ulexite

Figure 9: FT-IR spectrums of bio-oils obtained at $550{ }^{\circ} \mathrm{C}$. 


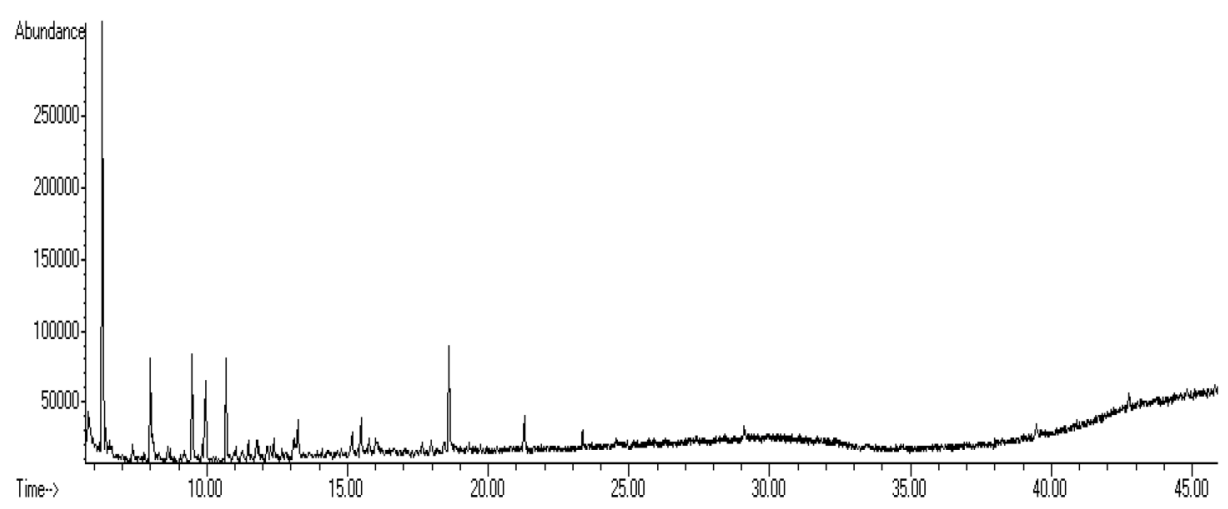

a) Without catalyst

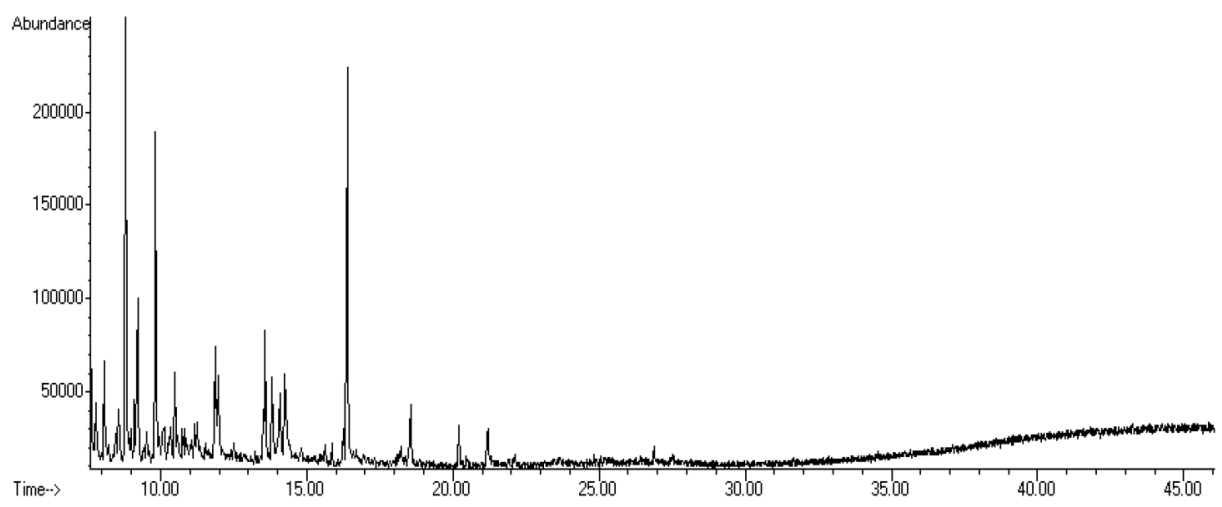

b) With tincal

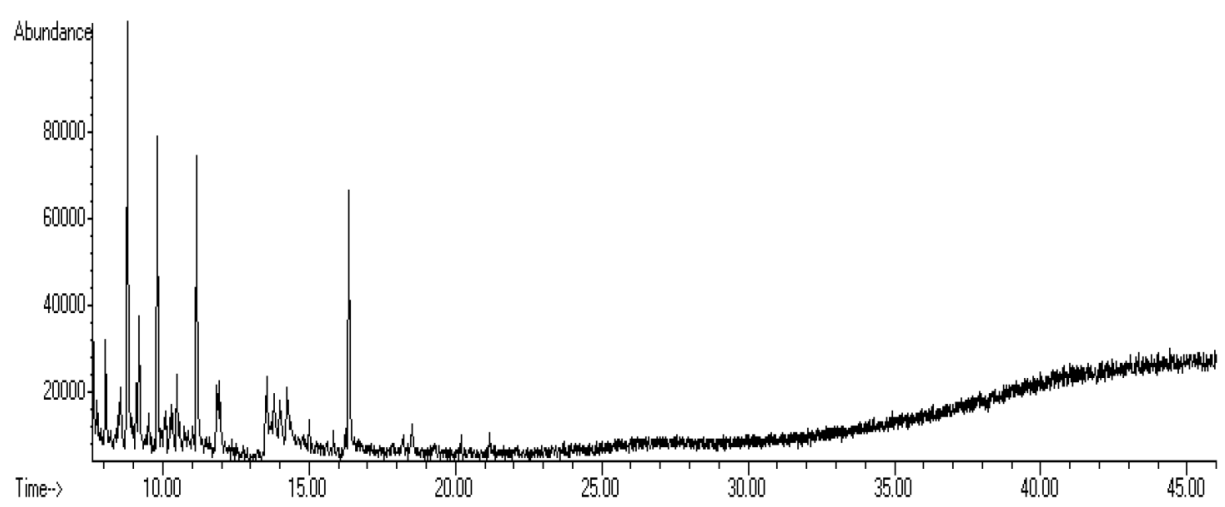

c) With colemanite

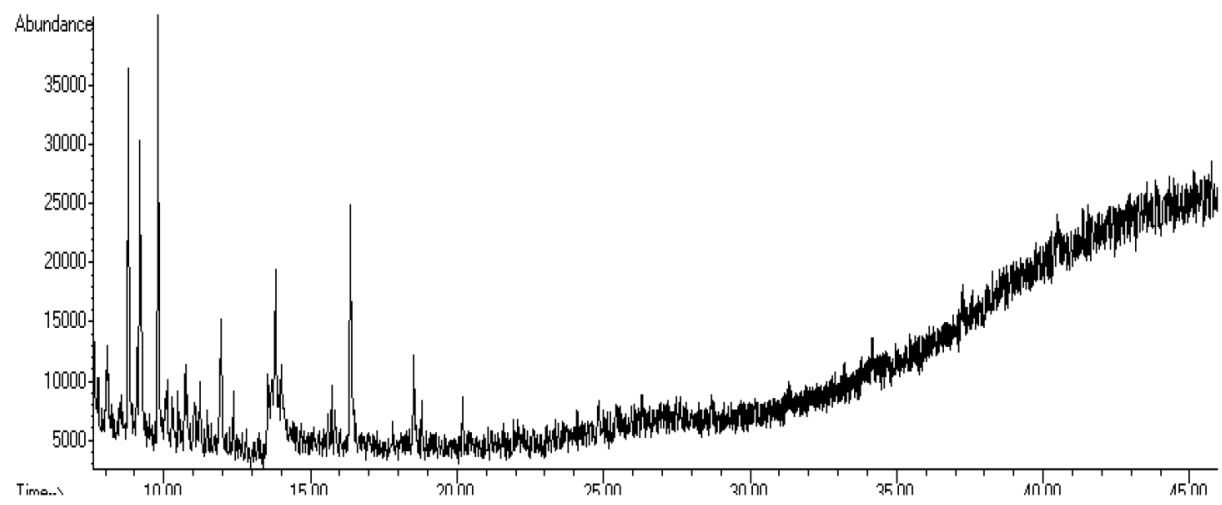

d) With ulexite

Figure 10: The total ion chromatograms of bio-oils obtained at $550{ }^{\circ} \mathrm{C}$. 
Table 5: Main Chemical Compounds Present in the Bio-Oils Obtained at $550{ }^{\circ} \mathrm{C}$

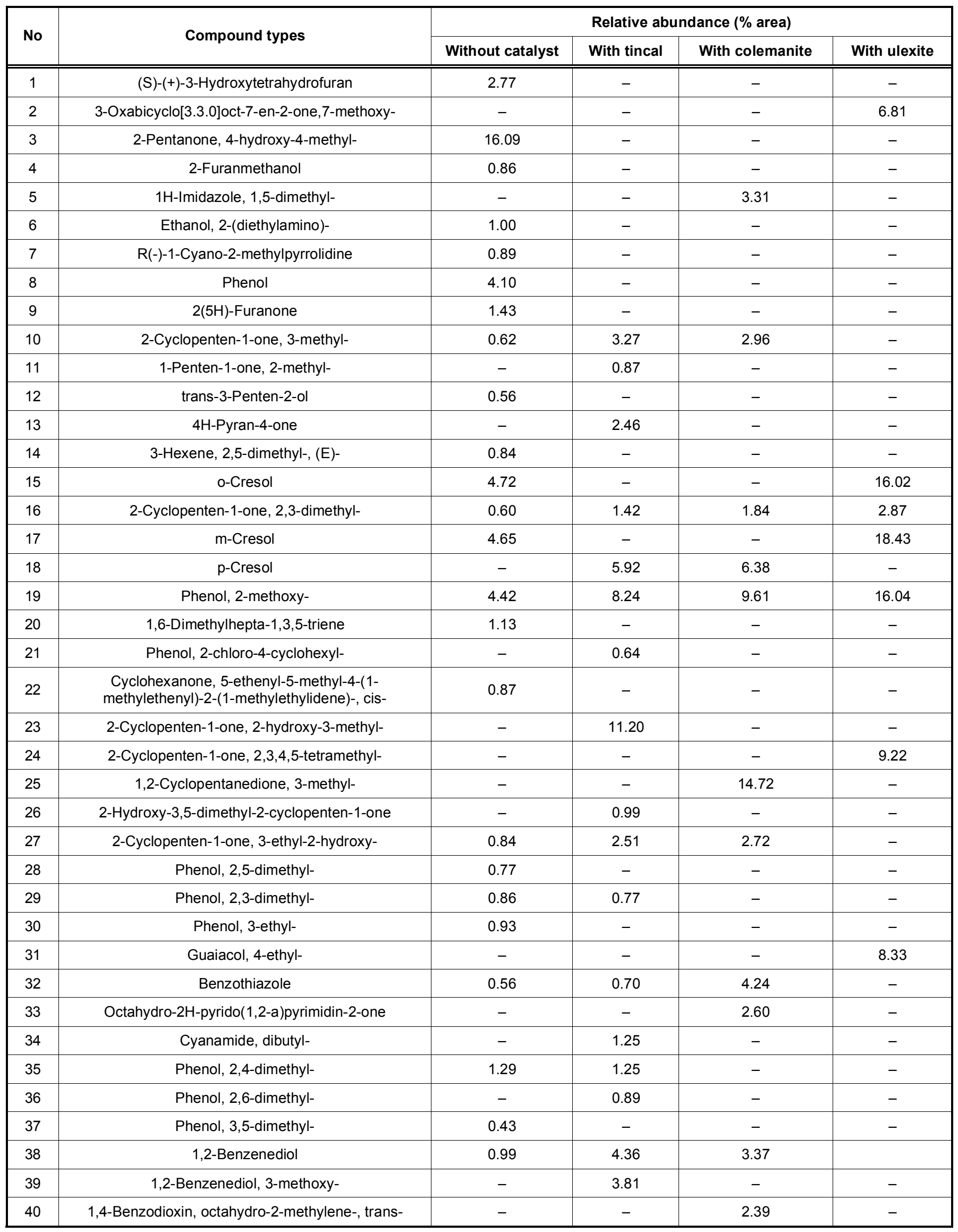


(Table 5). Continued.

\begin{tabular}{|c|c|c|c|c|c|}
\hline \multirow{2}{*}{ No } & \multirow{2}{*}{ Compound types } & \multicolumn{4}{|c|}{ Relative abundance ( $\%$ area) } \\
\hline & & Without catalyst & With tincal & With colemanite & With ulexite \\
\hline 41 & Hydroquinone & - & 4.73 & 5.53 & - \\
\hline 42 & Phenol, 2-ethyl- & - & 1.21 & - & - \\
\hline 43 & Phenol, 2-methoxy-4-methyl- & 2.64 & 4.27 & 3.89 & - \\
\hline 44 & 2-Hexene, 3-methyl-, (Z)- & 1.59 & - & - & - \\
\hline 45 & Cyclohexene, 4-propyl- & - & 0.71 & - & - \\
\hline 46 & Phenol, 4-ethyl-2-methoxy- & 2.00 & - & - & - \\
\hline 47 & 1,4-Benzenediol, 2-methoxy- & 1.18 & - & - & - \\
\hline 48 & 1-Hepten-3-ol-6,6-D2 & - & - & 11.79 & - \\
\hline 49 & 4-Mercaptophenol & - & 1.16 & - & - \\
\hline 50 & 2-tert-Butyl-pyrroline & 2.42 & - & - & - \\
\hline 51 & 2-Methylenethiacyclopentane & & 0.57 & - & - \\
\hline 52 & Benzoic acid, 2,6-dimethyl- & 0.83 & - & - & - \\
\hline 53 & $\begin{array}{l}\text { 7-Oxabicyclo[4.1.0]heptane, 1-(1,3-dimethyl-1,3- } \\
\text { butadienyl)-2,2,6-trimethyl-, (E)- }\end{array}$ & 0.77 & - & - & - \\
\hline 54 & 7-Methyl-2-oxa-7-azatricyclo[4.4.0.0(3,8)]decane & - & 1.66 & - & - \\
\hline 55 & $\begin{array}{l}\text { Bicyclo[3.1.0]hexan-2-one, 4-methyl-1-(1- } \\
\text { methylethyl)-, (1.alpha.,4.beta.,5.alpha.)- }\end{array}$ & - & - & 1.77 & - \\
\hline 56 & 1,2,4-Triazolo[4,3-b][1,2,4]triazine, 6-methyl- & - & 2.43 & - & - \\
\hline 57 & $\begin{array}{c}\text { 1,4-Benzodioxin, } 4 a, 5,6,7,8,8 a-h e x a h y d r o-2-m e t h y l- \\
\text { trans- }\end{array}$ & - & 1.09 & - & - \\
\hline 58 & Bicyclo[2.2.1]heptan-2-one, 5,5,6-trimethyl-, exo- & - & - & 1.47 & - \\
\hline 59 & 1,4:3,6-Dianhydro-.alpha.-d-glucopyranose & - & 5.74 & - & - \\
\hline 60 & 1,4-Benzenediol, 2-methyl- & 0.90 & 1.12 & - & - \\
\hline 61 & 5,5-Dimethyl-1,3-hexadiene & - & 1.17 & - & - \\
\hline 62 & Phenol, 2,6-dimethoxy- & 5.44 & 10.26 & 10.51 & 15.64 \\
\hline 63 & 1H-Purin-6-amine & - & - & 0.98 & - \\
\hline 64 & 1H-Inden-1-one, 2,3-dihydro- & - & 0.96 & - & - \\
\hline 65 & Chavibetol & 1.95 & - & - & - \\
\hline 66 & Cis-2,3-epoxyheptane & - & - & 5.92 & - \\
\hline 67 & 2-Tert-butyl-4-(hydroxtmethyl)-5-formylfuran & - & 1.34 & - & - \\
\hline 68 & 3,5-Dimethoxybenzoic acid & 1.17 & - & - & - \\
\hline 69 & $\begin{array}{c}\text { (5-Ethyl-cyclopent-1-enyl)-methanothiophene, 2- } \\
\text { propyl- }\end{array}$ & - & 0.94 & - & - \\
\hline 70 & $\begin{array}{l}\text { 5-Isopropenyloxymethylene-3,3-dimethyl- } \\
\text { cyclohexanone }\end{array}$ & 0.73 & - & - & - \\
\hline 71 & $\begin{array}{l}\text { 2H-1,4a-Ethanonaphthalen-1-ol, octahydro-, } \\
\text { (1.alpha.,4a.beta.,8a.alpha.)- }\end{array}$ & - & 2.16 & - & - \\
\hline 72 & Naphtho[1,2-c]thiophene, 1,3-dihydro-, 2-oxide & 0.35 & - & - & - \\
\hline 73 & 5-Propionyloxy-pent-3-enoic acid, ethyl ester & - & 0.86 & - & - \\
\hline 74 & 2-Azido-2,4,4,6,6-pentamethylheptane & - & 1.21 & - & - \\
\hline 75 & 1-Thienylcyclohexene & - & - & - & 6.63 \\
\hline 76 & Phenylbenzene & 25.79 & - & - & - \\
\hline 77 & Benzene, 1,4-dimethoxy-2-methyl- & - & - & 4.00 & - \\
\hline 78 & Benzenethiol, o-isopropyl-, & - & 3.64 & - & - \\
\hline 79 & Benzoic acid, 4-hydroxy-3-methoxy- & - & 2.21 & - & - \\
\hline
\end{tabular}


breakdown product during thermal treatment, but other anhydroglucoses, furan and furan derivatives are also produced. Phenols and derivatives such as phenol, 2,6-dimethoxy, guaiacol and cresols, the majority of the compounds in bio-oils were the primary products of decomposition of lignin $\left(280-500{ }^{\circ} \mathrm{C}\right)$ during pyrolysis [50].

The FT-IR spectrums of bio-oils (Figure 9) are consistent with the list of compounds in Table 5. The band intensities show that the most abundant chemical bonds in bio-oils are $\mathrm{O}-\mathrm{H}, \mathrm{C}-\mathrm{H}, \mathrm{C}-\mathrm{O}$ and $\mathrm{C}=\mathrm{O}$. Absorbance peaks of the $\mathrm{O}-\mathrm{H}$ vibrations between 3200 and $3400 \mathrm{~cm}^{-1}$ indicate the presence of the abundant compounds of phenolics. The typical carbonyl group $(C=O)$ streching vibrations at about $1700 \mathrm{~cm}^{-1}$ prove the presence of aldehydes, ketones or carboxylic acids in bio-oils. Presence of alcohols and esters can be confirmed by $\mathrm{C}-\mathrm{H}$ bending vibrations between 900 and $1200 \mathrm{~cm}^{-1}$ and $\mathrm{C}-\mathrm{O}$ stretching vibrations between 1200 and $1300 \mathrm{~cm}^{-1}[51]$.

\section{CONCLUSION}

In this study, pyrolysis of Cirsium yildizianum, a waste biomass, was performed in a fixed-bed reactor with and without catalyst to produce bio-char and biooil. The effects of pyrolysis parameters including temperature and boron catalysts were investigated on product yields and composition. The experimental data showed that the highest liquid (bio-oil) yield of $40.62 \%$ including aqueous phase was obtained in the presence of colemanite $(10 \%)$ at $550{ }^{\circ} \mathrm{C}$. Tincal has proven to have greater effect than other catalysts in improving quantity and quality of produced bio-oils.

The composition of the bio-oils was characterized by chromatographic and spectroscopic techniques as well as the calorific values of bio-chars and bio-oils. The bio-oils were found to be heterogeneous complex mixtures of monoaromatics, polyaromatics aliphatics, oxygenated and nitrogenated organic compounds. The FT-IR spectrums showed that the composition of biooils was dominated by phenolics and oxygenated compounds. The produced bio-oils had higher calorific values than the raw material. The GC-MS results of bio-oils indicate that Cirsium yildizianum could be used to produce bio-oils with higher heating values or valuable chemicals.

\section{REFERENCES}

[1] Meier D, Faix O. State of the art of applied fast pyrolysis of lignocellulosicmaterials - a review. Bioresource Technol 1999; 68: 71-7. http://dx.doi.org/10.1016/S0960-8524(98)00086-8
[2] Butler E, Devlin G, Meier D, McDonnell K. A review of recent labora-tory research and commercial developments in fast pyrolysis and upgrading. Renew Sustain Energy Rev 2011; 15: 4171-86.

http://dx.doi.org/10.1016/j.rser.2011.07.035

[3] Patil PT, Armbruster U, Martin A. Hydrothermal liquefaction of wheat straw in hot compressed water and subcritical water-alcohol mixtures. J Supercrit Fluid 2014 (In Press)

[4] Xiu S, Shahbazi A. Bio-oil production and upgrading research: a review. Renew Sust Energ Rev 2012; 16: 440614. http://dx.doi.org/10.1016/j.rser.2012.04.028

[5] Lin $\mathrm{Y}$, Tanaka $\mathrm{S}$. Ethanol fermentation from biomass resources: current state and prospects. Appl Microbiol Biot 2006; 69: 627-42.

http://dx.doi.org/10.1007/s00253-005-0229-x

[6] Matsumura $Y$, Minowa T, Potic B, et al. Biomass gasification in near- and super-critical water: status and prospects. Biomass Bioenerg 2005; 29: 268-92. http://dx.doi.org/10.1016/j.biombioe.2005.04.006

[7] Toor SS, Rosendahl L, Rudolf A. Hydrothermal liquefaction of biomass: A review of subcritical water technologies. Energy 2011; 36: 2328-42. http://dx.doi.org/10.1016/j.energy.2011.03.013

[8] Mosier N, Wyman C, Dale B, Elander R, Lee YY, Holtzapple $M$, Ladisch $M$. Features of promising technologies for pretreatment of lignocellulosic biomass. Bioresource Technol 2005; 96: 673-86.

http://dx.doi.org/10.1016/j.biortech.2004.06.025

[9] Jourabchi SA, Gan S, Ng HK. Pyrolysis of Jatropha curcas pressed cake for bio-oil production in a fixed-bed system. Energy Convers Manage 2014; 78: 518-26.

http://dx.doi.org/10.1016/j.enconman.2013.11.005

[10] Bridgwater AV. Fast Pyrolysis of Biomass: A Handbook, Volume 2, Aston University, Bio-energy Research Group, UK, 2002.

[11] Yaman S. Pyrolysis of biomass to produce fuels and chemical feedstocks. Energy Convers Manage 2004; 45: 651-71.

http://dx.doi.org/10.1016/S0196-8904(03)00177-8

[12] Zhang Q, Chang J, Wang T, Xu Y. Review of biomass pyrolysis oil properties and upgrading research. Energy Convers Manage 2007; 48: 87-92.

http://dx.doi.org/10.1016/j.enconman.2006.05.010

[13] Lu Q, Wenzhi L, Xifeng Z. Overview of fuel properties of biomass fast pyrolysis oils, Energy Convers Manage 2009; 50: 1376-83.

http://dx.doi.org/10.1016/j.enconman.2009.01.001

[14] Leiyu Z, Hongmin Y, Hao W, Meng W, Daqian C. Catalytic pyrolysis of rice husk by mixing with zinc oxide: Characterization of bio-oil and its rheological behaviour, Fuel Process Technol 2013; 106: 385-91.

http://dx.doi.org/10.1016/j.fuproc.2012.09.003

[15] Tekin K, Akalın MK, Bektaş S, Karagöz S. Hydrothermal wood processing using borax decahydrateand sodium borohydride. J Anal Appl Pyrol 2013; 104: 68-72. http://dx.doi.org/10.1016/j.jaap.2013.09.008

[16] Shadangi KP, Mohanty K. Thermal and catalytic pyrolysis of Karanja seed to produce liquid fuel. Fuel 2014; 115: 434-42. http://dx.doi.org/10.1016/j.fuel.2013.07.053

[17] Kadereit JW, Jeffrey C. (eds.). Flowering plants. Eudicots: Asterales. - In: Kubitzki, K. (ed.), The families and genera of vascular plants, vol. 8: 132. Springer- Verlag, BerlinHeidelberg, 2007.

[18] Arabacı T, Dirmenci T. Cirsium yildizianum (Asteraceae: Cynareae), a new species from East Anatolia, Turkey. Ann Bot Fenn 2011; 48: 503-6. http://dx.doi.org/10.5735/085.048.0610 
[19] Aysu T. Supercritical fluid extraction of reed canary grass (Phalaris arundinacea). Biomass Bioenerg 2012; 41: 139-44. http://dx.doi.org/10.1016/j.biombioe.2012.02.024

[20] Aysu T, Küçük MM. Biomass pyrolysis in a fixed-bed reactor: Effects of pyrolysis parameters on product yields and characterization of products. Energy 2014; 64: 1002-25. http://dx.doi.org/10.1016/j.energy.2013.11.053

[21] Aysu T. Catalytic pyrolysis of Eremurus spectabilis for bio-oil production in a fixed-bed reactor: Effects ofpyrolysis parameters on product yields and character. Fuel Process Technol (In Press)

[22] Tappi Test Methods. Tappi Press, Atlanta, Georgia, 1998.

[23] Wise LE, John EC. Wood chemistry. second ed., New York, Reinhold Publishing, 1952.

[24] Liu HM, Xie XA, Li MF, Sun RC. Hydrothermal liquefaction of cypress: Effects of reaction conditions on 5-lump distribution and composition. J Anal Appl Pyrol 2012; 94: 177-83. http://dx.doi.org/10.1016/j.jaap.2011.12.007

[25] Sun PQ, Heng MX, Sun SH, Chen JW. Analysis of liquid and solid products from liquefaction of paulownia in hot-compressed water. Energy Convers Manage 2011; 52: 924-33. http://dx.doi.org/10.1016/j.enconman.2010.08.020

[26] Durak H, Aysu T. Effects of catalysts and solvents on liquefaction of Onopordum heteracanthum for production of bio-oils. Bioresource Technol 2014; 166: 309-17. http://dx.doi.org/10.1016/j.biortech.2014.05.051

[27] García L, Salvador ML, Arauzo J, Bilbao R. Catalytic pyrolysis of biomass: influence of the catalyst pretreatment on gas yields. J Anal Appl Pyrol 2001; 58-59: 491-501. http://dx.doi.org/10.1016/S0165-2370(00)00114-5

[28] Antonakou E, Lappas A, Nilsen MH, Bouzga A, Stöcker M. Evaluation of various types of AL-MCM-41 materials as catalysts in biomass pyrolysis for the production of bio-fuels and chemicals. Fuel 2006; 85: 2202-12. http://dx.doi.org/10.1016/j.fuel.2006.03.021

[29] Chen G, Spliethoff H, Andries J, Fang, M. Catalytic application to biomass pyrolysis in a fixed bed reactor. Energy Sources 2003; 25: 223-8.

http://dx.doi.org/10.1080/00908310390142271

[30] Maguyon MCC, Capareda SC. Evaluating the effects of temperature on pressurized pyrolysis of Nannochloropsis oculata based on products yields and characteristics. Energy Convers Manage 2013; 76: 764-73.

http://dx.doi.org/10.1016/j.enconman.2013.08.033

[31] Aysu T. Production and Characterization of Bio-Chars and Bio-Oils Formed by Pyrolysis of Persian Hogweed (Heracleum persicum Desf.) in A Fixed-Bed Reactor, Journal of Applied Solution Chemistry and Modeling 2013; 2(4): 205-15.

[32] Azargohar R, Nanda S, Kozinski JA, Dalai AK, Sutarto R. Effects of temperature on the physicochemical characteristics of fast pyrolysis bio-chars derived from Canadian waste biomass. Fuel 2014; 125: 90-100.

[33] Peters JF, Petrakopoulou F, Dufour J. Exergetic analysis of a fast pyrolysis process for bio-oil production. Fuel Process Technol 2014; 119: 245-55.

http://dx.doi.org/10.1016/j.fuproc.2013.11.007

[34] Demiral I, Kul SC. Pyrolysis of apricot kernel shell in a fixedbed reactor: Characterization of bio-oil and char. J Anal Appl Pyrol 2014; 107: 17-24. http://dx.doi.org/10.1016/j.jaap.2014.01.019

[35] Shadangi KP, Mohanty K. Production and characterization of pyrolytic oil by catalytic pyrolysis of Niger seed. Fuel 2014: 26: $109-15$ http://dx.doi.org/10.1016/j.fuel.2014.02.035
[36] Ateş $F$, Işıkdağ MA. Influence of temperature and alumina catalyst on pyrolysis of corncob. Fuel 200; 88: 1991-7.

[37] Zhou L, Yang H, Wu H, Wang M, Cheng D. Catalytic pyrolysis of rice husk by mixing with zinc oxide: Characterization of bio-oil and its rheological behavior, Fuel Proces Technol 2013; 106: 385-91. http://dx.doi.org/10.1016/j.fuproc. 2012.09.003

[38] Huber GW, Iborra S, Corma A. Synthesis of transportation fuels from biomass: chemistry, catalysts and engineering. Chem Rev 2006; 106: 4044-98 http://dx.doi.org/10.1021/cr068360d

[39] Williams PT, Chishti HM. Two stage pyrolysis of oil shale using a zeolite catalyst. J Anal Appl Pyrol 2000; 55: 217-34 http://dx.doi.org/10.1016/S0165-2370(00)00071-1

[40] Güllü D. Effect of catalyst on yield of liquid products from biomass via pyrolysis. Energ Source 2003; 25: 753-65. http://dx.doi.org/10.1080/00908310390207783

[41] Encinar JM, Beltrán FJ, Ramiro A, González JF Pyrolysis/gasification of agricultural residues by carbon dioxide in the presence of different additives: influence of variable, Fuel Process Technol 1998; 55: 219-33. http://dx.doi.org/10.1016/S0378-3820(98)00052-6

[42] Wang Z, Wang F, Cao J, Wang J. Pyrolysis of pine wood in a slowly heating fixed-bed reactor: Potassium carbonate versus calcium hydroxide as a catalyst. Fuel Process Technol 2010; 91: 942-50. http://dx.doi.org/10.1016/j.fuproc.2009.09.015

[43] Jennings W, Shibamoto T. Qualitative Analysis of Flavor and Fragrance Volatiles by Glass Capillary Gas Chromatography. New York: Academic Press. 1980.

[44] Adams RP. Identification of Essential Oil Components by Gas Chromatograph Quadrupole Mass Spectroscopy. Allured Publishing Corporation, Carol Stream, USA. 2001.

[45] Moraes MSA, Georges F, Almeida SR, Damasceno FC Maciel GPS, Zini CA, Jacques RA, Caramão EB. Analysis of products from pyrolysis of Brazilian sugar cane straw, Fuel Process Technol 2012; 101: 35-43.

\section{http://dx.doi.org/10.1016/j.fuproc.2012.03.004}

[46] Tekin K, Karagöz S, Bektaş S. Hydrothermal conversion of woody biomass with disodiumoctaborate tetrahydrate and boric acid. Ind Crop Prod 2013; 49: 334-40. http://dx.doi.org/10.1016/j.indcrop.2013.05.014

[47] Chen Y, Yang F, Wu L, Wang C, Yang Z. Co-deoxyliquefaction of biomass and vegetable oil to hydrocarbon oil: Influence of temperature, residence time, and catalyst, Bioresource Technol 2011; 102: 1933-41. http://dx.doi.org/10.1016/j.biortech.2010.08.038

[48] Parparita E, Brebu M, Uddin MA, Yanik J, Vasile C. Pyrolysis behaviors of various biomasses. Polymer Degradation and Stability $2014 ; 100: 1-9$. http://dx.doi.org/10.1016/j.polymdegradstab.2014.01.005

[49] Peng C, Zhang G, Yue J, Xu G. Pyrolysis of lignin for phenols with alkaline additive, Fuel Process Technol 2014; 124: 212-21.

\section{http://dx.doi.org/10.1016/j.fuproc.2014.02.025}

[50] Hill CAS. Wood modification chemical, thermal and other processes, John Wiley \& Sons Ltd, The Atrium, Southern Gate, Chichester, West Sussex PO19 8SQ, England, 2007.

[51] Gomez-Serrano V, Piriz-Almeida F, Duran-Valle CJ, PastorVillegas J. Formation of oxygen structures by air activation. A study by FT-IR spectroscopy, Carbon 1999; 37: 1517-28. http://dx.doi.org/10.1016/S0008-6223(99)00025-1 